\title{
Research on Strengthening College Students' Ideology Security Education
}

\author{
Zhongyi Tang \\ School of Marxism \\ Wuhan University of Science and Technology \\ Wuhan, China 430065
}

\author{
Fang Song \\ School of Marxism \\ Wuhan University of Science and Technology \\ Wuhan, China 430065
}

\begin{abstract}
Under the current background of economic globalization, information networking and social transformation, the ideological field is facing severe challenges.And the ideological safety education for college students is also facing difficulties and problems. Therefore, to understand the current ideological and political status of college students in China, to recognize and analyze the current problems in the education of ideological safety for them, and then to put forward strategies to strengthen and improve the education,has important theoretical and practical significance in promoting the overall healthy development of college students,safeguarding our country's ideology and construct a socialist harmonious society.
\end{abstract}

Keywords-college students; ideological safety education; strategy

\section{INTRODUCTION}

Ideology security is directly related to Chinese national security and indirectly affects the country's economic construction. Colleges as important positions for ideological safety education for students, bear the responsibility to make a good education for them. We have summarized and analyzed the problems existing in the ideological safety education for college students in China. The concept of ideological safety education in colleges is lagging behind and not innovative. Colleges do not attach importance to social practice teaching. The level of practical education lags behind. Colleges neglect the construction of campus culture and cultural activities lack the spiritual core. The media construction in colleges is insufficient, the education function of colleges is not fully utilized, and the mechanism of teacher team construction is not consummate and runs inconsistently. We have proposed a series of effective measures, such as strengthening the ideological security construction of college students basing on the ideological and political theory courses, continuously increasing the attraction of the courses; attaching importance to ideological safety practice education and making full use of it; further strengthening the construction of college campus culture and continuously expanding the cultural path of education; actively grasping the media carriers of universities and forming an all-round ideological safety education dissemination system; and strengthening the construction of ideological safety education teams in colleges.

\section{THE IMPORTANCE OF STRENGTHENING THE IDEOLOGICAL SAFETY EDUCATION FOR COLLEGE STUDENTS}

Ideological work is an extremely important work for the party and our country. Colleges as forward positions of ideological safety education have long been responsible for safeguarding national security and cultivating top-notch talents. Therefore, it is extremely important and necessary for colleges to strengthen ideological safety education.

\section{A. Colleges Are Always an Important Position for College Students' Ideology Security Education}

Although the rapid development of network science and technology has led to the rapid rise of network culture, and has gradually made the Internet become the main field in China for ideological and political education and spread, and due to the open, complicated and virtual characteristics of network platforms, there is a mixture of good and bad information. There are both feudal ideas and western ideologies. Some students in universities lack the sense of national identity and national honor, and they know little about the national ideology. Therefore, it is extremely important to strengthen ideological safety education among the groups that have not yet reached a consensus on the core values of socialism and have not yet had a clear understanding of national sovereignty and territorial security. The carrier of universities is also relatively safe and stable.

\section{B. Ideological Security Is Directly Related to Chinese National Security and Indirectly Affects National Economic Development}

Ideology security not only helps to maintain the legitimacy of state power and ensure political stability, but also guides and promotes national economic development. Ideology as a conceptual superstructure counteracts productivity and production relations. Therefore, ensuring ideological security will help create a harmonious and stable environment for economic development, promote economic development, and maintain the steady and orderly development of Chinese economy. In addition, in the current international and domestic environment, it is urgently needed that colleges strengthen the ideological safety education for college students in order to boycott the threat of Western Ideology to the Security of Ideology in China. 


\section{THE PROBLEMS IN IDEOLOGICAL SAFETY EDUCATION FOR COLLEGE STUDENTS IN CHINA}

\section{A. The Idea of Ideological Safety Education in Colleges Is Lagging Behind and Lacks Innovation}

The ideological and political theory courses as the main approach for ideological safety education for college students, for a long time, have adopted the indoctrination mode which neglects the different levels of educational objects, doesn't consider psychological development characteristics of different college student groups, and even more, and ignores university students' psychological needs. Such education methods have put college students and educators on opposite sides, and it is difficult for students to accept and recognize educational content from their hearts. At the same time, the content of ideological safety education is not specific enough. Some educators only pay attention to the teaching of political concepts, lacking profound content, failing to stimulate students' thirst for knowledge, and greatly reducing the effect of classroom education on ideological safety for college students. In addition, the methods and content of college students' ideological safety education are lacking innovations, leading to a disconnection between theory and practice, which has caused the undergraduates to fail to achieve a true understanding and comprehension of the essence of Marxism. These also affect the play of the superiority of Marxist ideology, and have a certain negative impact on ideological safety education in colleges.

\section{B. Do not Pay Attention to Social Practice Teaching, Practice Education Lags Behind}

The safety education of college students is not only a theoretical study, but also a combination of practice and theory. Social practice education as an important means to strengthen the ideological safety education for college students, is of great significance for students to understand the society, understand national conditions, cultivate their character, and enhance their sense of social responsibility. At present, many colleges still have misunderstandings in practice teaching or do not recognize the importance of extracurricular activities. There is no corresponding system or management model. It is often just to organize students to send out leaflets on streets or in communities, make students do some simple social publicity or organize several voluntary activities. No innovation of practical activities in a real sense, results that students become bored with social practice activities. At the same time, there is a lack of professional practice instructors, and there is no emphasis on the themes, methods, and requirements of practice activities. This leads to the arbitrariness in practical teaching of ideological safety education for college students both in the form and the content. This makes students have no thoughts and minds. So the practical teaching of ideological safety education for college students lost its true meaning.

\section{Neglecting the Construction of Campus Culture, Campus Cultural Activities Lack Spiritual Core}

Campus culture can purify the mind, cultivate sentiment, and improve college students' perception of the Three Views. It is a good educational resource. At present, contrasting to the development requirements of college students' ideological safety education, colleges often neglect the cultural construction that can truly benefit students. They only focus on image and facility construction, landscaping, but lack rational planning for campus culture. They don't understand the function and role of ideological safety education comprehensively enough. The goal of ideological safety education cannot be truly and actively implemented. At the same time, colleges don't pay enough attention to the formation of college students' ideologies and values. Campus cultural activities lack spiritual core. Although colleges have cultural clubs and carry out various cultural activities, most of them are focused on entertainment and interesting characteristics. There is a lack of guidance on the ideological education of college students. Some campus cultural activities have obvious immediate and utilitarian tendencies, and there is no long-term and sound mechanism to guarantee the conducting of cultural activities. In addition, many unfavorable factors still exist in campus culture, which influence the formation and development of correct ideology of college students.

\section{Inadequate Media Construction in Colleges, Insufficient Play of Education Functions}

College is an important carrier of media for carrying out ideological safety education for college students and plays an important role in ideological safety education. In modern society, mass media, including newspapers, magazines, radio, television, movies, and the Internet, especially the rapidly developing new forms of media in recent years such as blogs, microblogs, and WeChat, have influenced the thinking ways and behaviors of college students. At the same time, it contains a large amount of negative and vulgar information, which not only increases the difficulty of college students in making right value choices and moral judgments, but also weakens and impacts the already formed ideology of college students. In addition, the status quo of the construction and operation of college media is not optimistic. Many colleges still use the school newspaper, radio and television as main transmissions, ignoring to exploit and use computers and mobile phones which are the most intimate tools of college students. There is a tendency of pan-entertainment, such as using the campus media as a tool for news propaganda, not investing in ideological safety education. In addition, although some schools have special websites for ideological and political education, the content conveyed on them are often abstract and empty. It is difficult for students to become interested in it because it is separated from students' real lives.

\section{E. Incomplete Teacher Training Mechanism and Inconsistent Operation}

The key to the ideological safety education for college students is the teachers. At present, some colleges still do not pay enough attention to the construction of teacher teams for 
the ideological safety education. There are some problems such as inadequate teachers, unfixed teams and unreasonable structure. In face of a large number of college students due to college enrollment expansion, the teachers for college ideological security education is far from enough. In addition, the overall quality of the education team is not high. Many college ideological and political theory teachers lack basic Marxist theoretical knowledge and a broad knowledge structure. At the same time, due to the lack of clear planning and specific measures, no scientific assessment system and effective incentive mechanism has been established, which has made the implement of improving working conditions, further vocational training, providing welfare benefits, etc. difficult to realize for the education team. The occupational and professional development of ideological safety education teams has been hindered, and educational resources have been seriously lost and wasted.

\section{TACTICS ON STRENGTHENING THE IDEOLOGICAL SAFETY EDUCATION FOR COLLEGE STUDENTS}

Colleges are not only the main positions for educating people, but also the forward position of national ideological construction and important positions for the building of socialist spiritual civilization. Because of this, it is extremely important to make effective strategies for ideological safety education for college students. In order to solve the problems in current college students' ideological safety education, we should do some things from the following five aspects. So that can ensure the realization of ideological safety education goals.

\section{A. Always Make the Ideological and Political Theory Courses be the Main Channel, and Continue to Increase Its Attraction}

Ideological and political theory course as the main channel to the college students' ideological safety education, should give full play to its positive role. First of all, we must update the teaching philosophy, and pay attention to training the theoretical thinking ability of college students. We must not only let students know what the Marxist theory is, but also make them understand why Marxist theory is like this, so that they can grasp the development law of Marxism. This requires the teachers be good at combining the theoretical viewpoints in materials with the social reality, and introducing the curriculum content with social hot issues so as to inspire students' interest and improve the efficiency in class. Second, we must improve teaching methods and fully mobilize the enthusiasm and initiative of college students. For the ideological and political theory courses in colleges, classroom teaching and theoretical instillation are necessary, effective and basic. However, classroom teaching must be continuously innovated as the changing of students' conditions. Finally, we must make innovation of teaching methods to enhance the appeal of the class. There are many methods making full use of multimedia technology to enrich the teaching content is an effective method. This is the direction of innovation in teaching methods. The teachers of ideological and political theory courses should make full use of modern educational technology to reform and transform teaching methods. Using instructional multimedia, combining abstract, profound theories with sounds and images, teachers should present the content to students vividly and intuitively to make the classroom teaching attractive and infective.

\section{B. Improve the Practice Education of Ideological Safety and Make It Fully Play Its Role}

The social practice activity is an important part of the education for college students and a good way to improve the practicality and effectiveness of ideological safety education. In order to fully realize the function of social practice education, firstly we should change ideas. On the one hand, leadership and practical organization departments should pay attention to practical education and increase support and guidance for social practice activities. On the other hand, college students should also attach importance to and participate in social practice activities, cherish the opportunities. During the process of practice activities, students should gradually set goals for self-development and self-improvement, and complete various practical tasks. Secondly, the form of social practice in colleges should also be continuously improved and innovated with the development of the world. For example, colleges can take the forms of military training, social investigations, visits and interviews, providing part time jobs, etc., to carry out national conditions education, patriotism education, collectivism education and the party policy education. So that students can fully understand the society, understand them, adhere to right political beliefs, improve moral qualities, and increase the sense of social responsibility and historical mission. Finally, we must standardize mechanisms for social practice education and clarify the responsibilities of various departments in colleges in social practice education for college students. In specific practical activities, we should pay close attention to individual practice conditions, guide students in choosing the theme of social practice activities, choosing methods, implementing activities, writing practice reports, etc., and clearly put forward the specific requirements of practice activities. In addition, we should improve the supervision of practical activities and improve assessment mechanisms to increase the enthusiasm of university students in participating in social practice and enhance the effectiveness of activities.

\section{Strengthen the Construction of Campus Culture in Colleges and Constantly Expand the Cultural Path of Education}

The construction of campus culture is not only one of effective ways for conducting ideological safety education for students, but also an important part of Chinese advanced cultural construction. Therefore, college leaders and relevant departments must attach great importance to the construction of campus culture and make it become an important part of school development. On the one hand, we must adhere to the development direction of advanced socialist culture, aiming at establishing college students' correct view of life and value, pay attention to the actual needs of college students, keep up with the pace of the times, constantly optimize and improve the cultural environment of college campuses. In addition, it should also be noted that the construction of campus culture in colleges is not an overnight task, nor can it be completed by a 
single department. Good campus culture depends on the joint efforts of all teachers, students and departments. On the other hand, we must scientifically and effectively conduct campus cultural activities and improve the value and quality of these activities. We must not only pay attention to the forms but also take into account the entertainment and attractive characteristics of the activities. So that we can fully realize the effectiveness of campus cultural activities in strengthening the ideological safety education for college students, and provide a strong spiritual power for cultivating qualified socialist builders and reliable successors. In addition to conducting lectures, academic exchange activities, literature and art activities, colleges should make use of off-campus resources, strive for obtaining support from all society, and expand the resources needed for carrying out cultural activities. Strengthen connection with communities, enterprises, military, museums, etc., and bring rich educational resources to construction of campus culture. We must well combine major festivals and education activities to conduct distinctive and attractive activities, enable college students to solve political and ideological issues in meaningful and colorful campus cultural activities, and promote the realization of college students' ideological safety education goals.

\section{GRASPING THE CARRIER OF COLLEGE MEDIA AND FORMING AN ALL-ROUND IDEOLOGY SECURITY EDUCATION PROPAGATION SYSTEM}

The development and application of network technology has brought new carriers, new platforms, and huge educational resources to ideological safety education for college students. Since the party's 18th National Congress, General Secretary Xi Jinping has made important speeches on cyber security and informationization on many occasions, pointing out the importance of using the Internet for carrying out ideological safety education under new conditions. Therefore, to strengthen the ideological security education of college students, colleges should strengthen the monitoring and management of campus network, take the initiative, be able to grasp the ideological dynamics of college students at the first time, and apply correct guidance and influence to college students through the campus network. Make the Internet an important position and means for spreading advanced culture and strengthening ideological safety education. To this end, colleges should, on the one hand, optimize traditional media carriers such as college newspapers, campus radio, and campus television to ensure that the contents in traditional media are healthy, elegant, and educational. In addition, students are encouraged to participate in all processes of campus media communication, to obtain fresh and vivid first-hand materials. This can make the content closer to the realistic life of college students and be more attractive and influential. On the other hand, use new media to build a new position for ideological safety education for college students. For example, create a theme website on ideological safety education depending on our own portal site; build an information exchange platform for ideological safety education using the emerging network interaction tools, and actively encourage responsible teachers and counselors to interact with students and give them correct guidance. Encourage teachers to actively participate in discussions and form a new front for ideological safety education.

\section{STRENGTHEN THE CONSTRUCTION OF THE}

IDEOLOGICAL SAFETY EDUCATION TEAM IN COLLEGES, GUARANTEE THE EDUCATION EFFECTIVELY

The first step of carrying out ideological safety education for college students is to attract superior personnel and build a team with high quality, reasonable structure, and full-used functions. Firstly, optimize the teaching team. Colleges shall, in accordance with the specific quality requirements of the education team summarized from the practice, scientifically formulate selection criteria, strictly follow the selection process, and select talents with high ideological, professional and psychological qualities. Further broaden the selection channels, innovate selection methods, in addition to strengthening the excavation of talents inside the school, also actively introduce talents outside the school and establish a talent reserve plan to ensure the high quality and high level of the ideological safety education team for undergraduates. Second, increase training for teachers and improve the overall quality of the ideological safety education team. Basing on the actual situation, colleges should prepare training plans, strengthen the cultivation for the education team in political quality, morality, professional and cultural qualities, educational skills and educational abilities, and improve modern teaching methods of the teachers. Finally, improve the management mechanism to ensure the effective running of the ideological safety education team. Combining with the actual conditions of the school's teaching staff, corresponding regulations shall be made for the rights and duties, status and treatment, qualifications and appointments, rewards and punishments of teachers engaged in ideological safety education in colleges, and for the selection and training of young teachers. And give a certain degree of policy inclination, formulate a consistent with the rules and regulations, to provide a strong guarantee for teachers engaged in ideological and safety education in colleges and universities.And give a certain degree of policy inclination to provide a strong guarantee for teachers engaged in ideological safety education in colleges.

\section{CONCLUSION}

Under the current background of globalization, networking, and Chinese social transformation, the issue of ideological safety education for college students is a topic which closely links to reality and is of great significance. It is also one of the key and difficult problems in Chinese ideological safety work. It is still very important and necessary to strengthen the ideological safety education for college students in the new era. Due to the lack of personal theoretical knowledge and practical experience, I am unable to do a deeper discussion on the strategies to strengthen the ideological safety education for college students. Some of the analysis is still superficial, which will prompt me to further strengthen the thinking on this issue in the future. I will strive to make results that are more valuable. 


\section{REFERENCES}

[1] Zhang Guo. Discussion on the construction of college students' ideological safety education mechanism[J]. Journal of Ideological and Theoretical Education, 2014(06),pp.105-108

[2] Qiu Xiaoyun. Reconsideration of the ideological safety education for college students [J]. Heihe Journal, 2014(02),pp.133-135.

[3] Zhang Yihan. Research on Contemporary Ideological Security Education of College Students in China[J]. Knowledge Economy, 2015(19),pp.118.

[4] Song Guangqiang, Zhang Fenghong. Challenges and countermeasures of contemporary ideological security in China[J]. Journal of Ideological and Theoretical Education, 2015(05),pp.103-106.

[5] Gao Xiang. Research on contemporary college students' ideological safety education [J]. Only Real (modern management), 2016(07),pp.5861.

[6] Gao Shijie. Thoughts on current ideological security work in colleges[J]. Journal of Ideological Education Research, 2016(05),pp.40-43.

[7] Bao Shumei. Research on the path of strengthening ideological security in colleges under the new media environment[J]. Economist, 2017(12),pp.199-200, pp.202.

[8] Liu Zexi. Analysis of College Students' Ideology Security Construction under the New Media Background[J]. Theory Guide, 2017(11),pp.103107.

[9] Wen Xiaoli. Study on the Predicament of Ideology Security Education for College Students in Qinghai[J]. Education Modernization, 2017, 4(43),pp. 225-228.

[10] Wang Ruirui. Challenges and Countermeasures of Contemporary College Students' Ideology Security Education[J]. Forum on Industry and Technology, 2017, 16(16),pp.11-12.

[11] He Yuanliang. Problems and Countermeasures of Undergraduates' Ideology Security Education: A Perspective of New Media Development [J]. Talents, 2017(14),pp.65 